\title{
Research Paper: Territorial Water Cooperation in Central Plateau of Iran and Its Role in Sustainable Rural Development: A Case Study in Yazd Province
}

\author{
Majid Labbaf Khaneiki ${ }^{1 *}$, Mohammad Reza Rezvani ${ }^{2}$, Dale Lightfoot ${ }^{3}$, Seyed Ali Badri ${ }^{4}$ \\ 1. PhD Candidate, Department of Human Geography, Faculty of Geography, University of Tehran, Tehran, Iran. \\ 2. Professor, Department of Human Geography, Faculty of Geography, University of Tehran, Tehran, Iran. \\ 3. Professor, Department of Geography, Faculty of Geography, Oklahoma State University, Oklahoma, USA \\ 4. Associate Professor, Department of Human Geography, Faculty of Geography, University of Tehran, Tehran, Iran.
}

\begin{tabular}{|l|l|}
\hline $\begin{array}{l}\text { use your device to scan } \\
\text { and read the article online }\end{array}$ & $\begin{array}{l}\text { Crtation: Labbaf Khaneiki, M., Rezvani, M. R., Lightfoot, D., \& Badri, S. A. (2017). Territorial Water Cooperation in Central } \\
\text { Plateau of Iran and Its Role in Sustainable Rural Development: A Case Study in Yazd Province. Journal of Sustainable Rural } \\
\text { Development, 1(2), 101-120. https://doi.org/10.29252/jsrd.01.02.101 }\end{array}$ \\
dol: : https://doi.org/10.29252/jsrd.01.02.101
\end{tabular}

Article info:

Received: 10 Jan. 2017

Accepted: 05 May 2017

Keywords:

Territory, Water cooperation, Shared water resources, Social capital, Qanat system

\begin{abstract}
A B STRACT
Purpose: This paper is aimed at examining two concepts of "territory" and "territorial cooperation of water" and then discusses three hypotheses on the role of shared water resources in strengthening cooperation between two or more beneficiary territories. Also, the paper aims to investigate the correlation between territorial water cooperation and social capital for sustainable development.

Methods: This study has been conducted through a qualitative method with ethnographic data collection and hermeneutic interpretation.

Results: The man-made water currents like qanat which are dependent on periodic maintenance can step up interaction and cooperation between different territories and accordingly blunt the territorial identity, in case they flow across two or several territories and benefit all of them. In other words, when a man-made stream which needs maintenance, crosses two or more territories, the territorial borders may gradually fade away which encourages more cooperation across the territories, and more cooperation result in vaguer borders and this cycle continues.

Conclusion: Water is one of the vital resources that a community within its territory needs to live on. However in many cases, neither surface streams nor groundwater are confined within the territory borders unlike the other resources such as soil, manpower, tools, infrastructures, etc. Therefore, the neighboring territories have to establish a cooperative relationship to ensure their sustainable access to their shared water, which can be called territorial water cooperation.
\end{abstract}

\section{Introduction}

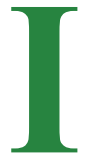

ran enjoys various climatic and geographical conditions so the inhabitants take various strategies to adapt themselves to their environments. In the central plateau of Iran, the climatic and geographical conditions gave rise to the technology of qanat which support the production systems in this region. Qanat consists of some shaft wells interconnected by a subterranean tunnels which drains out the

* Corresponding Author:

Majid Labbaf Khaneiki, PhD Candidate

Address: Department of Human Geography, Faculty of Geography, University of Tehran, Tehran, Iran.

Tel: +98 (938) 8509500

E-mail: labbaf_majid@yahoo.com 
groundwater seepage and conveys it onto the earth surface using the height difference between the two ends of the tunnel. Gravity propels water along a qanat tunnel. In other words, a qanat is an underground drainage system which collects groundwater at a mountain base and brings it to the less elevated areas (Behnia, 1988: 9). A typical qanat enjoys two main sections: water production section which cuts through water saturated soil and gets the groundwater infiltration, and water transport section which serves to transfer this water up to the earth surface.

In the past, central plateau of Iran had no water supply source but qanat to provide the agricultural and domestic sectors. Nowadays the urban sprawl and modern development have increased water demand beyond the supply of the ancient qanat system. Therefore many desert cities like Yazd have resorted to other alternatives such as tube wells and inter-basin water transfer to supply the required water. Overexploitation of groundwater has dramatically declined the groundwater resources and brought many qanats to the brink of annihilation. Qanat is considered a sustainable groundwater extraction technique that can guarantee a rational coexistence with nature.

A rich literature is available about the environmental, technical, cultural and historical values of qanat, however, few references exist on the role of qanat in territorial identities among its beneficiary societies. Although territorial identity or behavior can impede the development of fruitful cooperative activities, qanat system could build up a good capacity for cooperation and social convergence which can be used in configuring sustainable rural development and entrepreneurship. The structure of qanat which entails a vast spatial extent may pass across several territories whose inhabitants have to pull together in order to maximize their profit from its water. This study calls into question the common statement that water is always the matter of war and water scarcity in arid zones always triggers conflicts or nourishes oriental despotism.

\section{Definitions}

This study mostly deals with three concepts: "territory", "territorial cooperation of water", and "entrepreneurship" which are described in more detail under the topic of "Principle Concepts". Nevertheless, a brief definition of these terms helps us show what exactly this study revolves around.

\section{Territory}

A geographical boundary within which a human community is entitled to the existing vital resources, and their common interests, profits and threats can develop a sense of attachment to the same territory among the community members.

\section{Territorial cooperation of water}

Water is one of the vital resources that a community within its territory needs to live on. However in many cases, neither surface streams nor groundwater are confined within the territory borders as are the other resources such as soil, manpower, tools, infrastructures, etc. Therefore the neighboring territories have to establish a cooperative relationship to ensure their sustainable access to their shared water, which can be called territorial water cooperation.

\section{Entrepreneurship}

By entrepreneurship we mean creating new economic activities in line with sustainable development, drawing on the social and economic potentials embedded in the nature of water territorial cooperation.

\section{Study area}

The study area is Yazd Province, Iran (Figure 1), with an area of $74645 \mathrm{~km}^{2}$ and its capital is Yazd City with its unique adobe architecture. Yazd Province is located in the central plateau of Iran, whose elevation varies from $660 \mathrm{~m}$ above sea level in Rig Zarrin desert to $4055 \mathrm{~m}$ in Shirkooh mountain. Its annual precipitation is $103 \mathrm{~mm}$ on average, $40 \%$ of the whole country average. The province annually receives some 7.8 billion $\mathrm{m}^{3}$ of water as rainfall, which makes up $2 \%$ of the country amount. Distribution of annual precipitation over a year fluctuates so much, as $48 \%$ during winter to $40 \%$ in spring and $10 \%$ in fall and only $2 \%$ in summer. Moreover, drastic fluctuation in annual precipitation is frequent, and sometimes the territory has to go through several years of drought. These characteristics have had a discernible impact on social dynamic in the study area.

Low precipitation, high temperature and evaporation have deprived the province of permanent surface streams, except for two small rivers of Azam and Bavanat which originate in the elevations of neighboring Fars Province and flow across the border into Yazd Province. The total discharge of Azam is estimated to be 19.25 million $\mathrm{m}^{3}$ a year and this estimate is 15.79 for Bavanat, which both play a crucial role in replenishing the groundwater reserves in the plains of Herat and Marvast in Yazd Province. 


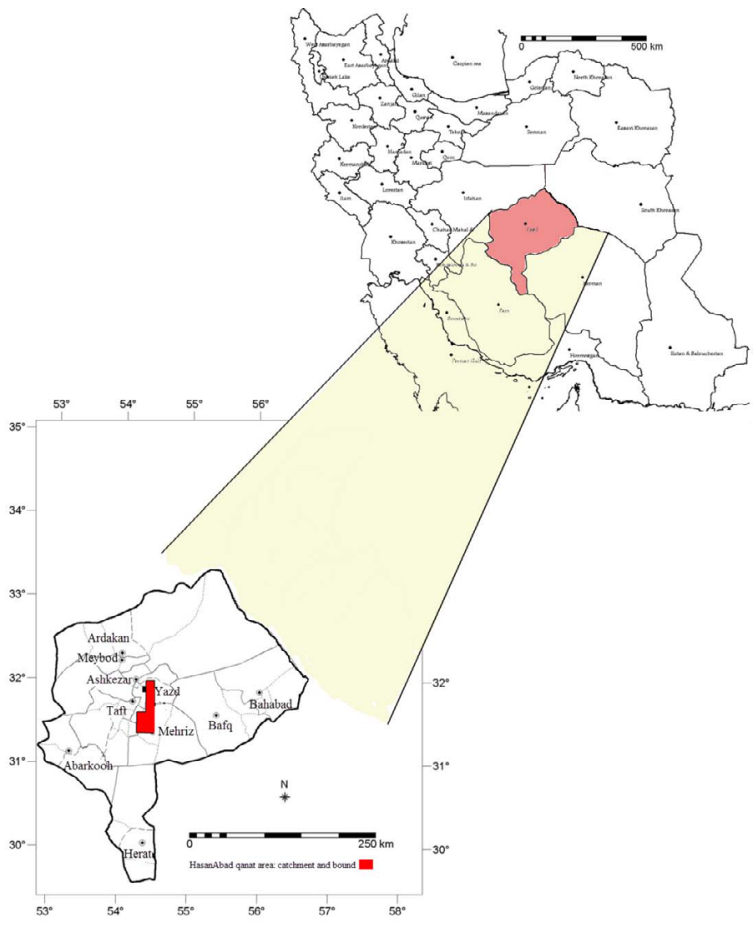

Figure 1. Location of Hasan Abad qanat

JSRD

Because of such climatic and geographic conditions, Yazd Province is highly dependent on groundwater resources, and almost all the water demanded by domestic, industrial and agricultural sectors is supplied through groundwater. Apart from a few karst aquifers, most of the province aquifers have formed in the layers of sediment which feed 6670 water sources including tube wells, springs and qanats, with a total discharge of 1378.8 million $\mathrm{m}^{3}$ a year. Out of this total discharge, $94.44 \%$ goes to agriculture, $3.58 \%$ to domestic sector, and $1.98 \%$ to industry.

In the past, groundwater was obtained through natural springs which were later outnumbered by qanats in the wake of historical climate changes. Qanat was a sustainable technique to extract groundwater, since it could keep in balance the groundwater input and output. The advent of tube wells over the past decades made significant inroads into the traditional qanats, and some of them fell into decay due to over-pumping and groundwater depletion. Nowadays groundwater drawdown is estimated to be between 1 and $1.6 \mathrm{~m}$ a year in Yazd Province. Nevertheless qanat still plays an important role in local economy and water supply in many parts of Yazd.

This study investigates the situation of groundwater resources shared by different territories within Yazd Province, with a focus on qanat of Hasan Abad. Based on

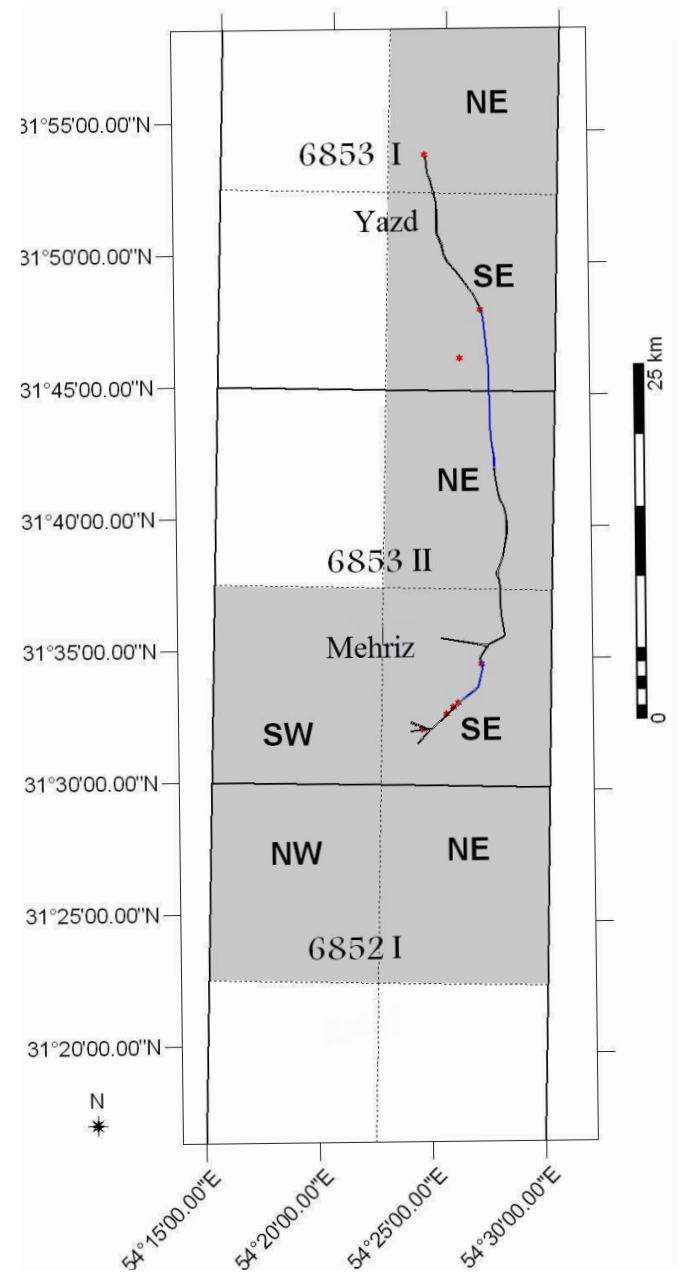

6 JSRD

Figure 2. Coordinates of important points along the passage of Hasan Abad qanat

our past research, the qanat of Hasan Abad in Yazd was chosen as our case study. Hasan Abad qanat originates from Ebrahim Abad valley near the town of Mehriz and travels $40 \mathrm{~km}$ to the city of Yazd. This qanat enjoys 1330 shaft wells, and according to a measurement made in 2016, its discharge amounts to $130 \mathrm{~L} / \mathrm{s}$. The shallowest well is $1.03 \mathrm{~m}$ and the deepest well is $17.8 \mathrm{~m}$ deep. This qanat enjoys the most discharge and also the highest quality compared to the other qanats in the region. Along its way from mother well down, the qanat passes across three territories and benefits them from its current (Labbaf Khaneiki \& Semsar Yazdi, 2015).

This study tries to answer four important questions about qanat and its role in boosting cooperation among different territories benefitting from it. They are as follows: 1 . In the central plateau of Iran, could the water resources management have increased the sense of co- 


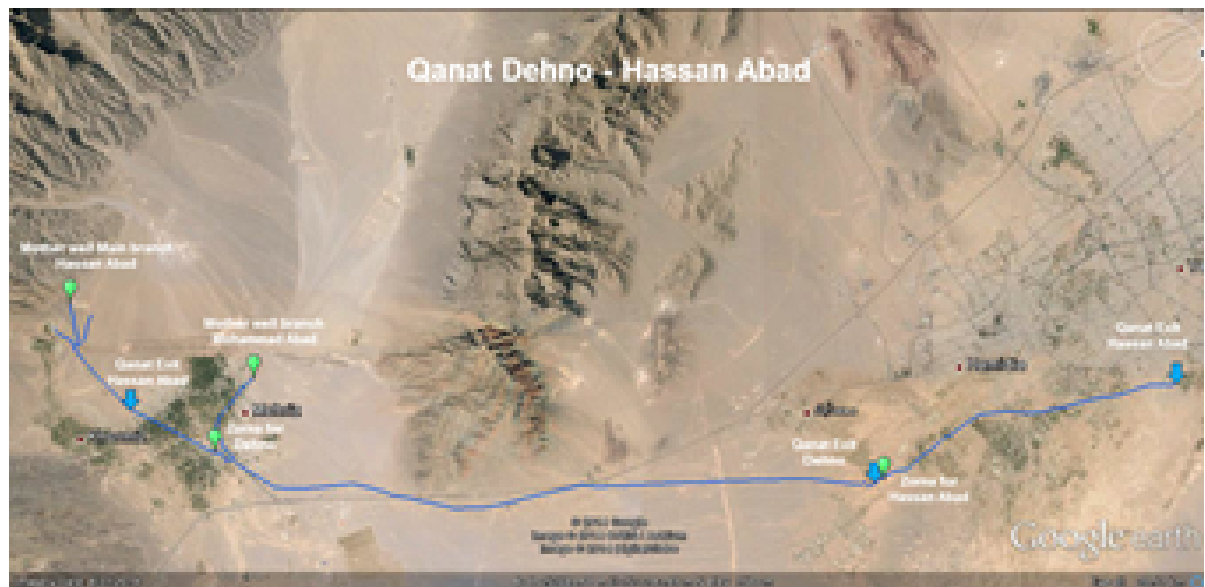

Figure 3. Direction of Hasan Abad qanat on google earth map

operation among the societies and foundations that have been formed and evolved around them?; 2 . Would the peculiarities of water resources lead to an increase in the level of social capital in the central plateau of Iran, and accordingly social capital bolster the sense of cooperation?; 3. Could the water related cooperation have reached out to the other social arenas regardless of whether this cooperation is based on habit or motiva-

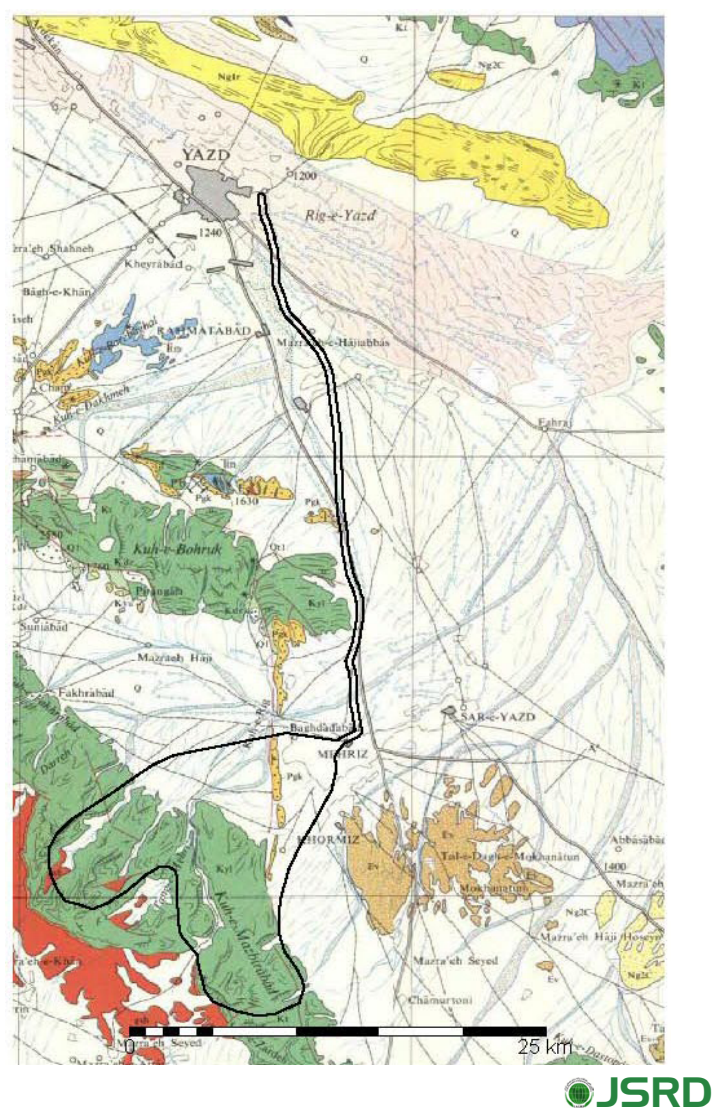

Figure 4. Bounds of Hasan Abad qanat based on its water catchment tion?; and 4. Is it possible to make use of such sense of cooperation and social capital in sustainable rural development and rural entrepreneurship in the study region if the hypothesis of this study proves true?

Therefore the questions of this study have to do with the concept of social capital. Dormant territorial behavior can pave the way for a high sense of cooperation and social capital, which are all associated mostly with the peculiarities of qanat.

The scholars have two prevailing approaches toward the relationship between social capital and cooperation. The first approach is discussed mostly in political sciences and economy, according to which, the social foundations can intrinsically habituate their members to cooperation. In other words, the cooperation needs to achieve organizational goals and protrudes from its own context, spread through the other social arenas, and finally turns into a social habit. That is why some scholars believe that many social behaviors are holdovers from the large game hunting which used to demand a high level of cooperation from the prehistoric humans (Tadie $\&$ Fischer, 2013). A social habit for cooperation sometimes conflicts with the personal profits of individuals, but cooperation is altogether in favor of the collective profit (Putnam, 2001).

The second approach is not as popular as the first one, and focuses on the concept of motivation rather than habit. According to this approach, the social foundations can systematically and logically generate the motivation required to continue the cooperation, which ensures the existence of those social foundations. In other words, an intricate relationship is formed among the members of a social foundation, from which the individuals feel obtain 


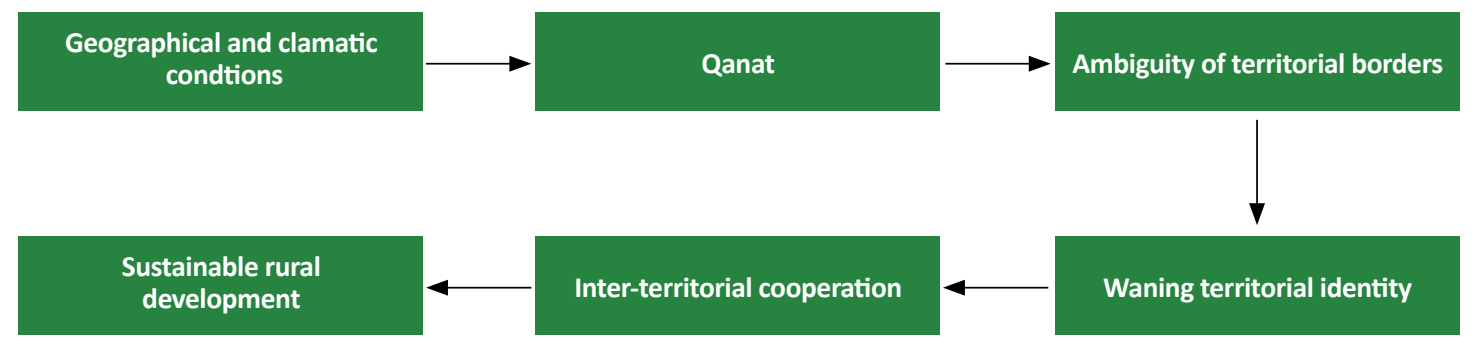

Figure 5. Role of qanat in strengthening territorial cooperation

maximum profit, through cooperation rather than egocentricism, selfishness, and cheating (Coleman, 1988).

On the other hand, cooperation seems to be one of the most important outcomes of social capital, so in turn a high social capital can result in more cooperation which facilitates the process of development. Antoci and others define social capital as a collection of re-generating and active properties, which is inherent in the social structure of a particular group, facilitating the cooperation between the group members in order to achieve their common goal. These properties are not on a par with physical factors of production or manpower, but more intangible (Antoci, Sacco, \& Vanin, 2010). Beard believes that social capital is kind of social relation which embraces trust, interaction and cooperation (Beard, 2005:23). Hayami contends that social capital is a system of unofficial social relations which develops more cooperation amongeconomic practitioners and eventually can increase the physical capital of those who play an active role in this system (Hayami, 2008:98).

\section{Hypotheses}

According to Schick, scientific hypotheses indicate what will happen if certain conditions are realized. By producing these conditions in the laboratory or observing them in the field, we can assess the credibility of the hypotheses proposed. If the predicted results occur, we have reason to believe that the hypothesis in question is true. If not, we have reason to believe that it is false (Schick, \& Vaughn, 2010). Therefore we want to examine the following three hypotheses through observing them in the field and desk studies:

1- Qanat, as the most vital water supply source in the central plateau of Iran, has not been able to fully meet the water demand of the growing population due to its structural peculiarities, so the qanat-based agricultural sector failed to absorb all the existing labor force. Thus the population overflow have turned to the industrial activities which were not that contingent on water. Growth of industrial activities then led to an increase in "mobility" which could influence the territorial behavior in the end.

2- The man-made water currents like qanat which are dependent on regular maintenance can strengthen interaction and cooperation between different territories and blunt the territorial identity, in case they flow across two or several territories and benefit all of them. In other words, where a man-made stream which needs maintenance run across two or more territories, the borders may fade which encourages more cooperation across the borders, and accordingly more cooperation can make the borders vaguer and this cycle continues.

3- The geographical and climatic conditions of the central plateau of Iran have ruled out the possibility of concentration of all vital resources (water, soil, workforce, etc.) within a certain territory. The dispersal of pivotal resources over the different territories can make them more dependent on each other and weaken the territorial identity. For example, where a territory enjoys a fertile soil but has to bring water from its neighbor, it cannot develop the sense of self-sufficiency which usually hinges on territorial identity.

\section{Literature Review}

In the central plateau of Iran, qanat is the pivotal source of water, which has always been at the center of the scholars' attention since hundreds of years ago. For example, in "Extraction of Hidden Waters" book by Haseb Karaji written around 1000 years ago, the techniques of qanat construction are discussed. This book examines the technical issues regarding qanat and tries to answer the common questions such as how to construct and repair a qanat, how to find groundwater reserves, how to do leveling, etc. Some of the innovations described in this book had been brought up for the first time in the history of hydrology, and some of its technical methods are still valid and can be applied in qanat construction. The content of this book implies that its writer, Karaji, did not have any idea on another book which had been compiled around the same time by some clergymen. Ac- 
cording to the "Incidents of Abdollah bin Tahir's Time" by Gardizi, in the year $830 \mathrm{AD}$, a terrible earthquake struck the town of Forghaneh and reduced many homes to rubble. The inhabitants of Neyshaboor came over to Abdollah bin Tahir and asked him to intervene, for they bickered over their qanats and they found the relevant instruction or law on qanat as a solution neither in the prophet's quotations nor in the clerics' writings. So Abdollah bin Tahir managed to bring together all the clergymen from across Khorasan and Iraq to compile a book entitled "Alghani" (The Book of Qanat). This book took up all the rulings on qanats which could be of use to whoever wanted to judge a dispute over this issue. Gardizi added that this book was still applicable to his time, and everyone made reference to this book (Labbaf Khaneiki \& Semsar Yazdi, 2015).

Apart from these ancient records, a considerable number of scholars have conducted valuable research on qanat as a vital water source in the central plateau of Iran in several languages from different points of view. One of the best works ever done in this respect is Lambton's paper which appeared in the conference proceedings on "Qanat, Kariz and Khattara" in 1998 in London (McLachlan, McLachlan, Bonine, \& Beaumont, 1989). The author has cited the book "Qanat; a Technique for Obtaining Water" and accepted Henry Goblot's idea about the genesis of qanat (Ibid: 5). Beaumont has contributed to the same proceedings by writing a paper entitled "The Qanat: A Means of Water Provision from Groundwater Sources" that well describes the technical mechanism of qanat and its indigenous engineering (McLachlan et al., 1989). Regarding qanat, another paper worth noting is "A New Approach Towards Qanat in Iran and Its Distribution Over Different Geographical Regions" by Hasan Ali Ghayour, published in the Persian language Journal of Geographical Research.

This paper suggests a different classification of qanats according to their geographical distribution (Ghayour, 1991). Also tens of papers have been authored by Javad Safinejad, the Iranian well-know qanat researcher, on different aspects of qanat and especially its water management system such as the paper "Ebrahim Abad Qanat, the Oldest Qanat of Iran". This paper has delved into the history of Ebrahim Abad Qanat as well as the traditional know how on its construction and maintenance (Safinejad, 1996). The International Center on Qanats and Historic Hydraulic Structures (UNESCO-ICQHS) built upon the results of this paper and eventually decided to nominate Ebrahim Abad Qanat for UNESCO World Heritage List.
One of the most well-known books on qanat is "Building and Looking after Qanat” by Abdol Karim Behnia. This book discusses the hydraulic and engineering aspects of qanat (Behnia, 1988) though it is silent about the territorial cooperation of qanat system.

Henry Goblot's book “Qanat; A Technique for Obtaining Water" is also of this kind, which has been translated into Persian by Sarvghad Moghaddam and Papoli Yazdi (Goblot, 1992). This book opens up the controversial issue of qanat genesis and its spread over the world, which were cited in many other references later. The book has brought up a theory on qanat genesis for the first time, but has not pointed out territorial cooperation of qanat; the issue we are looking for.

When it comes to the social and cultural aspects of territorial cooperation of qanat, numerous references on social systems and water management of qanat can be used in our research. In this respect, the late American geographer, Michael Bonine, did some precious works. For example, his paper "From Qanat to Kort: Traditional Irrigation Terminology and Practices in Central Iran" well portrays the indigenous water management systems in central Iran, which has been translated into Persian in 2004 (Bonine, 2004).

A part from the references ever prepared on general aspects of qanat, there are also some monographs which give insight into the subtle role of qanat in territorial cooperation at local level. For example, "Qanats of Bam from Engineering Point of View" (Semsar Yazdi, Labbaf Khaneiki, \& Dehghan Manshadi, 2005), "Qanats of Taft", (Papoli Yazdi \& Labbaf Khaneiki, 2004) and "Qanat of Qasabeh as a Myth" (Papoli Yazdi, Labbaf Khaneiki, Labbaf Khaneiki, Jalali, \& Vosoogh, 2000) books are subsumed among such references. The mentioned books shed light on the technical and cultural differences between the qanats, which reflect the inevitable role of geographical and environmental factors. This disparity between qanats appears as a great opportunity in tourism sector, the subject which has been examined in the book "Qanat Tourism" by Labbaf Khaneiki and Semsar Yazdi (2015).

Studying qanat with its different dimensions and capacities is a prerequisite for understanding territorial cooperation of qanat. One of the values of qanat is its intangible heritage which has not attracted much attention yet. Intangible heritage of qanat is manifest in its indigenous knowledge and engineering. Also the intricate water management system of qanat and folkloric customs and rituals regarding qanat are all subsumed under the 
topic of qanat intangible heritage which has fortunately been taken up in some books and qanats. For example, the book "Traditional Irrigation Systems in Iran" by Javad Safinejad, provides interesting information on water management of qanat and its social and cultural structures (Safinejad, 1989). Some of the facts that have appeared in this book can help us better configure the concept of territorial cooperation of qanat. Also the book "Water Division Systems in Iran" has been written about the traditional methods of qanat water distribution in rural regions of Iran (Labbaf Khaneiki, 2006). Water division across the territorial borders and its relevant social foundations are among the qanat intangible heritages which play crucial role in discouraging territorial behaviors.

This research has drawn on all these references to achieve a more accurate understanding of territorial cooperation of qanat and its potentials to promote sustainable development in the arid and semi-arid regions of Iran. Most of the discussions over the issue of water and territory revolve around the possible challenges and disputes over limited water resources within particular territories. In many previous studies, it is usually taken for granted that water is the source of conflict between neighboring territories and their discord deepens the gap between the territories, quite contrary to what this research tries to examine. Many books and articles have so far been published on the water induced conflicts among which one can mention a paper entitled "Federating and Defending: Water, Territory and Extraction in the Andes". This paper describes a confrontation over water between Peru, Bolivia and Ecuador, which has emanated from establishment of industries in the rural areas and the consequent water shortage (Bebbington, Bebbington, \& Bury, 2011). In such studies, water is a scarce resource within or between the territories, which can intensify the territorial identity and accordingly escalate the territorial behaviors. However, in this research we focus on water resources whose optimum exploitation necessitates maximum cooperation across the beneficiary territories, and this technical-social equation is inherent in the structure of such water resources in the central Iran, the issue which has been left unexplored.

\section{Methodology}

The common approach in human geography would adopt a quantitative method in a research like this, a method that usually begins with computation of data samples and ends up in statistical analysis of quantitative data. In humanities research, quantitative approach has been so much and blindly followed that in many cases it has deviated far from its philosophical and conceptual context, instead it is applied as a pragmatic prestige or empirical cover to remain under the definition of modern science. In fact, the quantitative approach in humanities has turned out to be a formal costume without which it is forbidden to set foot in the academia of knowledge. This extremist approach has distorted reality in some research in humanities, because we try to put the tight garment of quantity on the body of reality in any way, even though that reality has a qualitative nature per se. Therefore, we cannot utilize the potentials of an analytical interdisciplinary approach.

As a result, we examine such qualitative subject as "the impact of women's education on family emotional relationships" just through a quantitative method with the tool of controlled questionnaire (Mahdavi \& Hashemi, 2010). Sometimes we even overstep this boundary and employ the quantitative method in studying the religious concepts and use the Cochran equation in measuring topics like "the correlation between Quranic instructions and marital satisfaction in the family" and then reach the desired results (Aghpour, Mazaheri, Avazeh, \& Vahedi, 2012).

Nevertheless in realty, many of the humanities disciplines cannot be harnessed by the empirical methods and tools of modern natural sciences, and the marriage between humanities disciplines and methodology of natural sciences may result in the birth of a handicapped baby who does not enjoy much from the truth. Therefore, it seems better to deploy the qualitative method in the research of this kind that deal with intricate relationships among human, technology, and geography.

Qualitative research consists of a regular method to better investigate and understand the components of the conditions and characteristics of human phenomena which cannot be easily translated into quantitative data. In other words, qualitative research involves the gleaning, analyzing and interpreting of rich narrational information to understand the deep concepts and facts which have become very complicated due to the historical presence of humans (Khanifar \& Zarvandi, 2010:246). Qualitative research is a multidisciplinary approach which can be deployed in different disciplines of humanities. This approach has been fed and nourished by a variety of epistemological paradigms, and it also uses various methods and tools to delve as deeply as possible into the reality rather than predict future situations (Khodaverdi, 2008:43). Qualitative research is premised on social interpretivism-constructivism, whose findings cannot be achieved by mere statistical processes and through quantification. But information required for qualitative research is obtained mostly through personal observations, 
interviews, or long term interactions with a focus on the participants' concepts and interpretations. This type of research tends to draw the information by looking into the beliefs, values and behaviors in their own intact social context (Mohammadpour, 2013:93).

Nowadays qualitative research has gained a stronghold in many humanities disciplines such as social sciences and human geography. Until late 1960s, about $90 \%$ of the papers published in the reliable sociological journals in America used statistical and quantitative methods, but the hegemony of such methods waned over time. Critiques of positivism which encouraged steadfast quantification in humanities paved the way for the qualitative research to burgeon and develop during the next decades. Therefore by mid-1980s, qualitative research could come to the fore in social sciences (Silverman, 1985) and from 1990 on a third approach started to loom, which has risen amid the then conflict between quantitative and qualitative methods. Although this combined approach has a long history, it officially emerged since $1990 \mathrm{~s}$ in the wake of an end to the methodological wars between different paradigms, in which quantitative and qualitative methods came to mingle. The combined approach is based on both pragmatic principles and relativism (Mohammadpour, 2010:7).

Given the nature of the present research, we have opted for hermeneutic and interpretative methods which lie under the qualitative approach. Originally, hermeneutic only pertained to text interpretation, but later it made its way into the other disciplines of humanities. Dilthey considers it a privilege for humanities disciplines that their subject and object are inseparable and can understand and interpret each other because they share the human nature. That is why Dilthey recognizes hermeneutic as authentic research method for humanities (Papoli Yazdi \& Labbaf Khaneiki, 2000).

In a hermeneutic interpretation of text, the researcher tries to transfer himself/herself historically and psychologically to the possible position of the text author in order to achieve a better understanding of the text taking into account all the social, political, economic and cultural factors that might have affected the creation of a particular text. In the end, the researcher can come up with a more genuine interpretation of the text through reconstruction of the author's personality, time, and place. This text can also be a cultural element or a production system among a particular community or even a qanat with its complicated connection to territorial identity. Therefore in this method, more time and effort are devoted to investigating the subject and its environment from different points of view. Systematic analysis of our subject would lead us to discover its subtle relationships with other phenomena in its environment (Ibid).

In this research, hermeneutic means scrutinizing the books, articles, and documents regarding the concept of "territory" and studying the situation of qanats and other water resources in the region to get an accurate view of water issue in the desert human ecology and its position in the social and cultural fabric. Afterwards, we try to examine our hypotheses through a combination of holistic approach and deductive reasoning. This research benefits from both field and desk studies which in fact fall into the following four categories according to Marshall and Rossman: 1- active participation in the research, 2- direct observation, 3- comprehensive interviews, and 4- documents review (Marshall \& Rossman, 2002:109). In the research the same four categories have been deployed to obtain the required information. Active participation means that the researcher spends a considerable time in the study area to internalize the ongoing social and environmental processes (Marshall \& Rossman, 2002:109).

I have studied qanat system since 2000, and dwelled in the study area in the city of Yazd since 2005 in order to scrutinize different aspects of this traditional water supply technique. Therefore what Marshall and Rossman say about active participation has already taken place and still continues. Our field study is mostly based on observation and free or controlled interviews with locals, who play a crucial role in examining the research hypotheses and answering the research questions. In qualitative method, field study is regarded as an essential strategy to draw information and qualitative data. This type of field study is akin to participatory observation, because the researcher tries to look into the subject in its original context and genuine situation (Fadavi, 2012:217).

Some preplanned interviews would be done with the qanat practitioners. It is worth noting that most of these interviews are ethnographical whose time and location are less limited than the other types of interview in which a framework of time and location is determined. However, ethnographical interviews mostly emanate from ordinary contacts in the field. Flick believes that ethnographical interview is a set of intimate conversations into which some new elements would be injected by the interviewer in order to jog the interviewees' memories to provide the correct answers (Flick, 2012:184). Such interviews are very helpful to single out the sample qanat and also to find suitable solutions for drawing on its potentials for entrepreneurship. 
Based on the former studies, the qanat of Hasan Abad in Yazd was chosen as our case study. The qanat passes across three territories from its mother well down, that respectively benefit from its current. It is worth noting that the Delphi technique was used in the process of selecting the interviewees and conducting the interviews. Delphi technique in hermeneutic research is an acceptable way to reap the deeper layers of information from the selected interviewees just within the area of their own knowledge. This technique aims at reaching a consensus on a particular subject by raising some selected questions according to the research subject as well as the specialties of the interviewees (Hsu \& Sandford, 2007: 1).

Finally the acquired information would be analyzed and interpreted. Creswell contends that qualitative research is essentially interpretative, in which the researcher tries to pull aside the superficial layer to reach the ultimate meaning by interpreting the connections and interactions. Analyzing the persons themselves, their environment and the data used to produce the concepts and categories for the purpose of answering the research questions are all subject to this interpretation (Creswell, 2012:249). The interpretation of information can eventually yield some suggestions and solutions which directly or indirectly specify the role of qanat in the rural development and entrepreneurship.

\section{Findings}

Through our qualitative research method, the hypotheses were examined, and then we tried to answer the question of possibility of using the socio-political capacities of qanat in sustainable economic development and rural entrepreneurship in the region. Our hypotheses underline qanat and its structural and social characteristics as the main ground for territorial cooperation. Territorial cooperation is anchored in feeble territorial identity which is associated with uncertainty of territorial borders. We believe that it is feasible to employ the territorial cooperation as a social capital in sustainable rural development. In this research, our major findings are categorized in "territory", "territorial cooperation of water", and "entrepreneurship" which are described in turn as follows:

\section{Discussion}

In this research, our discussion revolves mostly around the three main concepts; "territory", "territorial cooperation of water", and "entrepreneurship" which are described respectively as follows (Figures 3-8):

\section{Territory}

Territory is known as one of the most important factors in mammals' behaviors. According to biologists, territorial behavior is exhibited by the members of a particular species to ensure exclusive utilization of a specified area of land which includes the limited vital resources such as food, shelter, and mate (Raven \& Johnson, 2001:556). Evolutionary approach raises an important question about territorial behavior: why do the species accept the cost of defending their own territories? In evolutionary biology such questions are usually answered from economic or functional point of view. Although territorial defense may come at a heavy cost for many species, the potential benefit gained from the defense would still be so high to take such a risk. This benefit can appear in the forms of more secured food, more access to mates, better shelter against the dangers or predators, and so on (Ibid).

Some scholars equate the principles of the territorial behaviors in human with that of some other mammals, and analyze what humans do in terms of territory. For example, Laura Smith makes an analogy between the gangs' territorial behaviors in Los Angles and the territorial behaviors of such mammals as wolves, and then she comes to the conclusion that the both follow the same pattern. She contends that the gangs specify their territories based on the existing spatial resources by drawing their own graffiti and special figures on the walls, like the wolves that spray their urine to mark their boundaries (Smith, Bertozzi, Brantingham, Tita, \& Valasik, 2012). The biologists' findings were later tuned up in the works of many scholars in humanities as well. Some believe that spatial territory means a limited space to which some individuals or groups are entitled as their exclusive area and they pull together to defend it whenever needed.

In the context of culture, territory is absorbed into our psychological identity and along with the sense of ownership it turns into some symbols (Ansari, Jamshidi, \& Almasifar, 2010:35). In different mythologies, one can find many examples about how territorial behavior has been exalted as a divine moral deed. For example, every Iranian boasts about their legendary champion Arash, the archer who was appointed following a truce to determine the border between Iran and its foe "Tooran". Both sides had agreed to recognize wherever Arash's arrow would land as their final border. The archer's patriotic morale was so strong that he sent out his soul to propel the arrow which flew as far as the river of Jeyhoon and ripped the trunk of a walnut tree. Arash's death has always been venerated as a hero who made such a sacrifice to preserve their sacred territory. 
Although territorial behavior is in fact anchored in our biological evolution, many layers of our culture has now engulfed it to such extent that its imprints are clearly visible in our religions, mythologies, literature, etc. Therefore, we cannot downgrade the territorial behavior in human only to biology which does not lead us to the truth due to the power of culture which may distort our nature to a large extent. Culture in human communities is so strong that it can divert, weaken, or sublimate some seemingly instinctive impulses. Thus in humanities, such concepts as territory and boundary are considered interdisciplinary, which engage many disciplines.

International law deals with such subjects as border conflicts and frontier treaties. Constitutional law clarifies the legal nature of territory and border, while administrative law takes up provincial borders and their subdivisions and federal territories. International relations pertain to the issues of territorial conflicts or interactions as well as the role of territory in the national power and sovereignty. History of international relations revolves around the past territorial tensions and competitions, while political geography examines the geopolitical, geostrategic and hydropolitical importance of the territories and borders, and political sciences see the border as the embodied concept of territory, which contributes to the formation of government (Khalili, 2011:8).

According to these definitions, the concept of territory always influence the process of decision making, and every planning takes place in the context of territory. Based on this approach, territory means a space in which all the members of a community claim the ownership of a particular area and recognize kind of collective governance. Therefore, these members should have the opportunity to participate in making decisions on public affairs, at least the decisions that can affect their livelihoods (Ambrosio-Albalá, Bastiaensen, 2010: 11).

\section{Water territorial cooperation}

What Reis says about the epistemology of territory mostly revolves around the interaction and sometimes conflict between the two key concepts which in fact underlie the social and economic structures: "mobility" and "territorialisation". Mobility is one of the peculiarities of the production factors, and describes the factors that go beyond a certain territory, and their optimum location is not dictated by spatial parameters. For example, the carpet workshops are more lucrative in the regions where more skillful workers are available. Therefore, the skill of carpet making carries the trait of mobility. But territorialisation pertains to some production factors whose optimum function relies on space, and spatial proximity is necessary for them to ensure their functional connections with other factors. For example, pasture is a production factor which is firmly fixed in territory and the nomadism economy is formed by a functional relationship between pasture and the other factors like livestock (Reis, 2012).

The notion of territory is associated with the interaction or conflict between the two mentioned concepts: "mobility" and "territorialisation". The more production factors in a society are anchored in territory, the stronger territorial identity would emerge, and then a power based on territory would develop. On the contrary, the more mobility the production factors enjoy, the weaker the territorial identity, and accordingly the less territory-based power would be built up. Reis's theory is a good starting point for investigating the issue of territory in our case study. Building upon this theory, one can assume a spectrum for territory, whose one extreme is nomadic economy based on animal husbandry and the other extreme is industrial economy.

In nomadic economy, most of the production factors are anchored in territory and their spatial proximity plays a vital role in their optimum function. Livestock, pasture, manpower, water resources, pastoral roads, and so on are all interwoven by systematic ecological and spatial relationships. For example, type and variety of livestock is selected according to the environmental conditions of the region and also is influenced by other production factors (Papoli Yazdi \& Labbaf Khaneiki, 2000a). Pasture is also limited by the environmental conditions, as a part of the intricate human ecology in the region, and has a territorial nature (Papoli Yazdi \& Labbaf Khaneiki, 2000b). But in the industrial economy, the most important factor is human skill which is used in making tools, using tools, manufacturing process, production planning and marketing. The other economies lie somewhere between these two extremes.

The most important question is where qanat has been placed on the spectrum the economy of Iranian central plateau and how. Our first hypothesis is that the structural peculiarities of qanat have not allowed it to supply enough water to the growing population, and the available water supply has always lagged behind the population growth, and accordingly the irrigated agricultural sector could not absorb all the available manpower. As a result, the manpower surplus turned to the local industrial activities whose water demand was much lower than that of agriculture. Therefore, development of such 


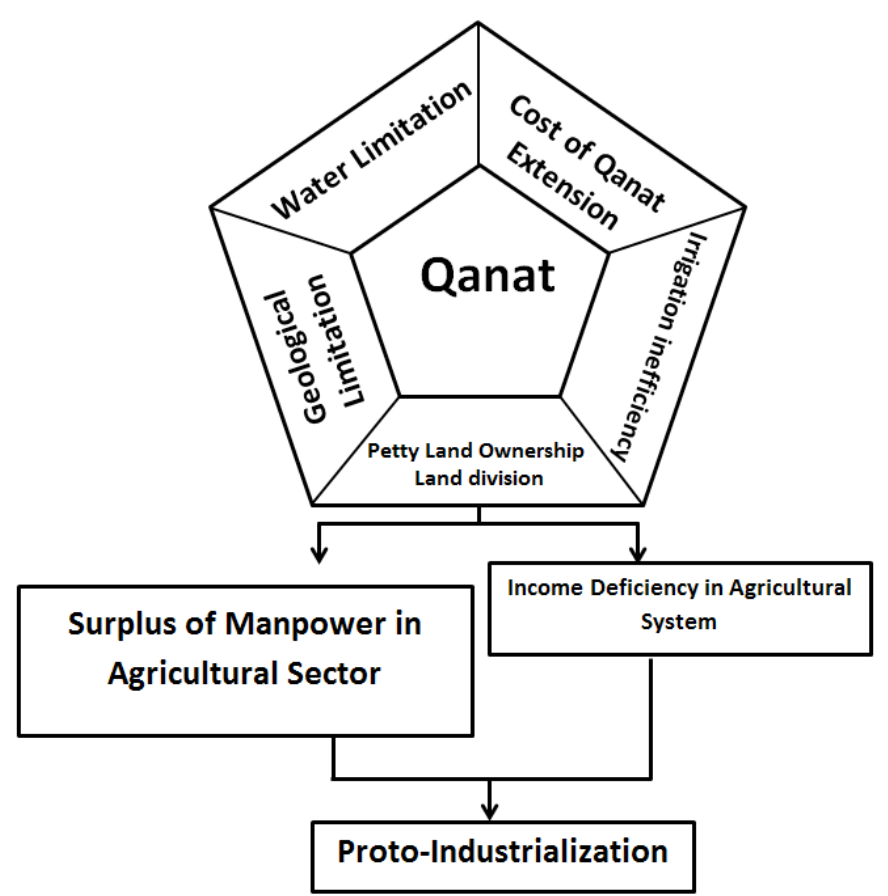

Figure 6. Conceptual model of qanat limitations and their role in the development of local industries

industries could lead to a rise in "mobility" which could influence the concept of territory.

The issue of environmental limitations and their impact on the development of industrial activities are neither new nor out of the academic debates. A deeper understanding of rural industries can shed light on the complicated relationship between "territory" and "production systems". The theory of "proto-industrialization" first appeared in Franklin Mendels's PhD dissertation and was then introduced to the literature of development in 1972 (Mendels, 1972). According to this theory, prior to modern industrialization in the west, in Europe, a kind of spontaneous organic industrialization came into existence between 16 and 19 centuries as a result of interactions between geographical conditions and socioeconomic predispositions (Ogilvie, 2008:1).

Those pre-modern industries expanded their influence area and worked their way into the markets even out of their local territories. Proto-industrialization was rooted in rural regions of Europe, and is regarded as the first stage of the modern industrial revolution in the west (Mendels, 1972:241). Proto-industrialization is premised on the fact that the climatic and geographical conditions in many European regions did not favor involvement in agricultural activities all year round, so the manpower temporarily detached from agriculture could pave the way for rural industries to flourish. Capital was gradually built up in rural industries, which could lead to more manpower being drained from agricultural sector, and such a cycle brought about more development for rural industries.

Development of rural industries in turn challenged many norms and mechanisms in the European societies, and the traditional systems started to loosen their hold, the systems that used to be very conservative and systematically keep the population growth in balance with the available economic resources. As a result, proto-industrialization pieced together all the essential elements needed for the launch of modern industrialization such as manpower, capital, liberalism, technical expertise, commercial and manufacturing enterprises, inter-regional markets, and so on, thus the economic destiny of west headed down a new path.

Nevertheless the theory of proto-industrialization was modified by some scholars like Levine who regarded proto-industrialization as part of a bigger process referred to as "proletarianization". Levine believed that proto-industrialization was followed by an abrupt population growth which disturbed traditional patterns of land ownership and social structures in rural communities. That process left a considerable population who no longer possessed enough farming lands for their livelihood and had to work for others in return for wage. Therefore manpower was transformed into a proletarian nature in the wake of proto-industrialization, which eventually gave rise to modern industrial revolution (Levine, 


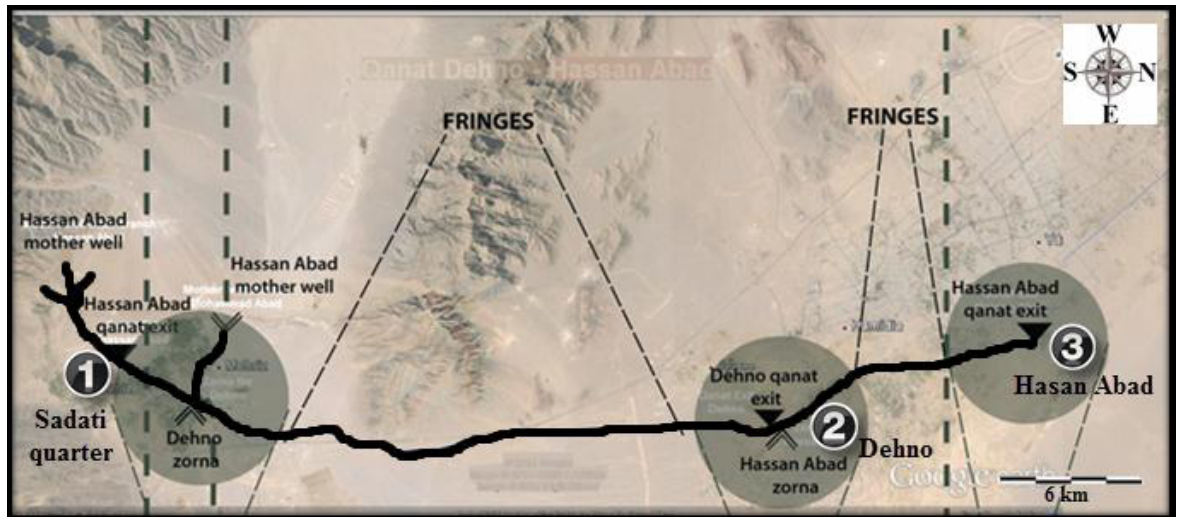

Figure 7. Territorial cooperation in qanat of Hasan Abad in Yazd, Iran

1977). Later some scholars like Kreidte tried to conflate the theories of Mendels and Levine in order to describe historical move of Europe from feudalism to capitalism (Kriedte, Medick, \& Schlumbohm, 1981:8). In all these interpretations, manpower or in general human capital remains as a key factor for industrialization process (Suarez-Villa, 1985:319).

Except for modern industrial revolution in relation to proto-industrialization, the same pattern of proto-industrialization has happened in the central plateau of Iran. Proto-industrialization is a complicated geographical, social, and economic process which is in fact rooted in the interaction between such different elements. These elements may come together and pave the way for proto-industrialization even out of European lands. For example, proto-industrialization also came about in Japan and later made it possible for modern industrialization to thrive there (Howell, 1992). Even in the central plateau of Iran, proto-industrialization produced through an interaction between geographical, social, and economic factors that gave rise to a capacity for modern industrialization, though this capacity was overshadowed by cultural hegemony of the surrounding Iran and stifled from beginning.

In fact in central plateau of Iran, qanat as the only water supply for agricultural production went with a technical limitation. Qanat could drain out just the overflow of groundwater based on gravity, the same water that came down in the shape of rain or snow at the top of some sparse elevations in the region. Therefore the area of farmlands was not able to keep pace with any increase in population, due to such a limitation in water supply (qanat). In Europe, the long winter put limitation on constant agriculture and drove people to invent a way to supplement their income using the surplus manpower from agricultural sector. In central plateau of Iran, the same process took place but because of water limitation instead of long freezing winters.
Thus in central plateau of Iran, small home industries could take advantage of this condition and thrive to a considerable extent. These industries played a crucial role in the economic structure of the region, the industries which rose to national and sometimes international fame such as Persian carpet, textile, silk, pottery, tile, glass, metal products, etc. Figure 2 shows this geographical-economic mechanism in more detail. In this model (Figure 2) qanat is impaired by some natural, technical and managerial limitations which are all associated with the structural peculiarities of qanat.

The first limitation is water itself which cannot be increased in proportion to its demand. The qanat tunnel is not typically higher than 160 and wider than 80 centimeters, into which groundwater seeps slowly, builds up and then flows down. Therefore it is not possible to obtain a huge water flow through a typical qanat. Although its water flow can be increased to some extent by digging further into the aquifer or building side branches (Semsar Yazdi \& Labbaf Khaneiki, 2016); other factors may keep such measures at bay. For example, geological condition is not usually homogenous in a particular region, so the extension of a tunnel or side branches may come across impassable barriers such as saline formations or hard rocks. Also the extent of aquifer and its hydraulic gradient are among the natural limitations which hinder more advances into aquifer. Moreover, the legal bound of neighboring qanats should be observed while extending the qanat gallery through water bearing zone.

In many cases there are other qanats adjacent to a qanat, all taking water from the same aquifer. Therefore a qanat advancing toward another qanat can decrease in its water flow, so this practice is forbidden by tradition and law. Even extending of a qanat should be carried out in relation to extending of neighboring qanats, which is calculated by a qanat expert based on the depth of each qanat. Figure 2 shows cost of qanat extension as another 


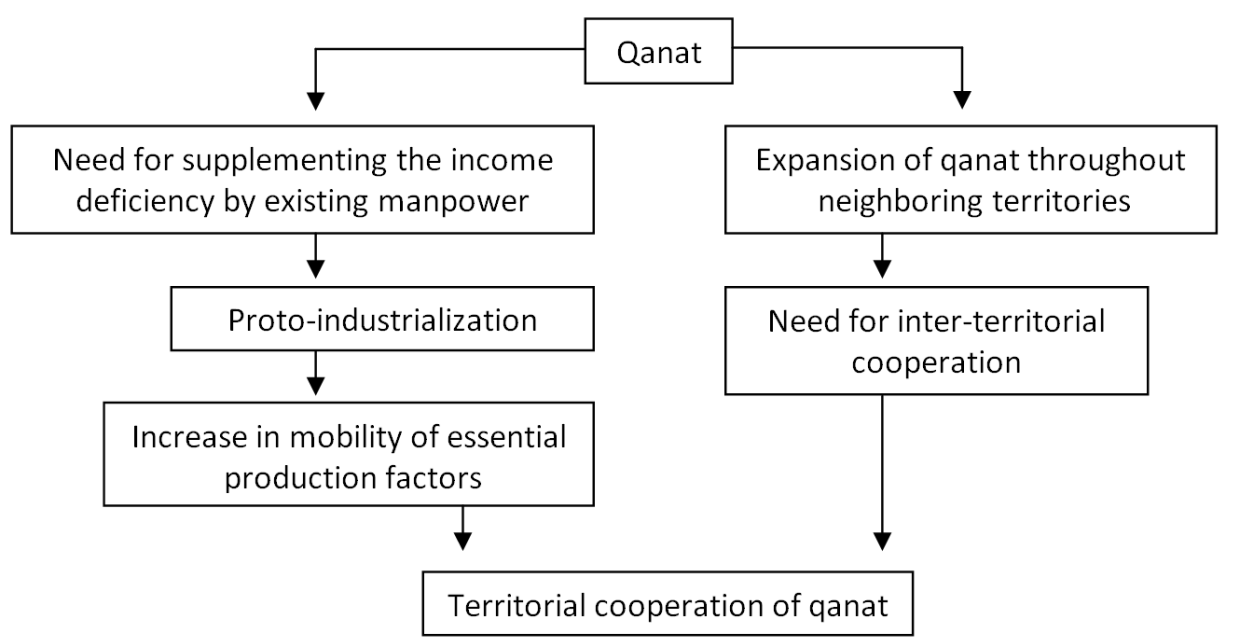

Figure 8. Role of qanat in reinforcing territorial cooperation

limitation. Qanat extension can increase the groundwater infiltration area along the tunnel and accordingly result in more water flowing out of qanat. But most qanats enjoy petty land ownership, owned by low income farmers who do not afford the high expense of constant extension.

Therefore qanat extension is a measure taken to retain the qanat flow or retrieve the same flow if qanat flow would dwindle. In other words, qanat extension serves to retain the present situation, and is not aimed at obtaining more water than the normal hydraulic regime of qanat. It should be also noted that qanat is usually used for surface (flood) irrigation with traditional earthen ditches in which a considerable portion of water percolate or evaporate. Therefore, the more the cultivated area expands and the more earthen open ditches would be built, the more water would escape by percolating and evaporating and the less irrigation efficiency.

Moreover, ownership structure of qanat hinders any more development in its agricultural system. Qanats mostly enjoy a joint ownership, and heredity makes water shares become smaller and smaller over time. On the other hand, ownership of water independent from land is considered another limitation for the development of qanat based agricultural systems. These factors altogether prevent qanat-based agricultural systems from expanding in order to feed the growing population, the population that increases with geometric progression, though the available water resource remains constant at best. Such limitations which are inherent in qanat-based agricultural systems do not allow the whole manpower to engage in agricultural sector, and pave the way for other economic sectors to play their role to supplement the income deficiency of agricultural sector. One of most important economic sectors in central plateau of Iran has been small local industries which have always served as the cornerstone of the financial and commercial processes in the course of history.

Qanat-based agricultural systems used to end up in agricultural products which were all usually consumed in this same region. But a considerable portion of industrial products were intended for exporting to as far other regions as China and India. One can liken those oases in the Iranian desert to some islands scattered across an ocean. Each island has a fragile agricultural system based on irrigational technique of qanat, which cannot provide the growing population with enough food. Therefore the islanders have to hone their skills in industrial and trading activities in order to barter their products for more food with other regions. Those islands have no next neighbors, but they have to travel a relatively long distance across the ocean to reach the first residential land. This example implies some similarities between the conditions that prevailed in the Iranian oases and in some islands like England. Therefore in central plateau of Iran, proto-industrialization led to the expansion of economic and commercial activities across the geography. This current of goods and capitals resulted from proto-industrialization in turn gave rise to some social consequences out of which "territorial cooperation" is of great importance.

Based on Reis's theory, in the central plateau of Iran, the pivotal role of small industries have enjoyed them more mobility and less territorialisation. As mentioned before, in industry there are fewer factors inseparable from land or each other. In industry, the most important factor is human skill which enjoys a high mobility in this 
sense. Therefore, industry is less susceptible to territory than agriculture, and agriculture is less sensitive to territory than nomadic animal husbandry. More mobility in this sense can wane "territory" and accordingly an uncertain territory makes it easier to coexist and cooperate across its border.

Other issues that help us better understand the concept of territory in central plateau of Iran are physical structure and managerial system of qanat which give rise to cooperation and social convergence. In many qanats like qanat of Hasan Abad (our case study), two or more villages are entitled to a particular qanat which is shared among them to everyone's benefit.

Qanat is a system with a vast spatial extent that may reach the length of tens of kilometers. Therefore taking care of such a system demands a close cooperation from all the shareholders. In most cases, there are some artificial recharge dams locally named Goorab upstream from a qanat. Those earthen dams served to trap the seasonal runoffs behind them and make the water seep into the earth and replenish the aquifer. The dams used to play a vital role in sustaining qanat discharge. The dams were not located in the territory of the direct beneficiaries of qanat, but they had to be built in the territory of another village up slope from the qanat. But those villagers raised no objection to the construction of such dams in their territory even though they could not gain from the qanat water at all because of height difference. They tolerated the presence of those dams, because they could take indirect advantage of the dams whose sediments were arable and quite suitable for dry farming. The sediments behind the dams provided enough moisture for the crops after water fully subsided and percolated through the ground to the aquifer. The damp sediments were regarded as an opportunity for the upstream villagers to cultivate with no need for irrigation.

In case of qanat of Hasan Abad, there are three regions lying along the qanat, each of which has a share of water. This qanat originates from southwest of Mehriz about $1 \mathrm{~km}$ northwest of Gharbalbiz spring, and travels some $40 \mathrm{~km}$ to the village of Hasan Abad on western side of Yazd outskirt, watering Sadati district in the town of Mehriz, village of Dehno and eventually Hasan Abad on its way. Sadati district is the first place where the gradient of tunnel allows water to appear on the earth surface. One fifth of water is allotted to Sadati district, and the rest is transferred to the next place through another underground tunnel.

The next place is Dehno which takes two fifth of qanat water and releases the rest for Hasan Abad through another underground tunnel. A 40 kilometer long tunnel from its mother well to its final exit point requires a constant maintenance, because any obstruction in the tunnel can come at a heavy cost for the three regions. If somewhere in the tunnel collapses and the ruin was not removed immediately, the water build-up can cause more collapses and hamper the function of qanat. The qanat runs across three territories and makes them all converge and cooperate. Moreover the qanat needs to be extended every year. In other words, the qanat gallery should advance a few meters a year into aquifer in order to keep the same flow.

The gallery extension is carried out upstream of qanat and in the vicinity of its mother well in Mehriz territory, though the two other territories also team up. Also, if the qanat downstream needs to be repaired or cleaned out, the upstream territories do not hesitate to cooperate. The dynamic of qanat transcends the concept of territory and accordingly the territorial identity wanes and cooperation and convergence across the border become more feasible.

Our second hypothesis can be restated as follows: such man-made water conduits or canals as qanat whose operation depends on periodic humans' care, can weaken territorial cooperation and then strengthen cooperation between different territories, while passing across two or several territories and benefiting all of them. In this case the territorial borders would become more uncertain, which paves the way for more cooperation and interaction, and more cooperation can make the borders more uncertain and this cycle continues.

This hypothesis can hardly be extrapolated to natural streams of water like rivers and springs and sometimes the reverse is true, though some scholars completely rule out considerable number of conflicts over water - even natural streams - in the course of history. Dinar contends that "water war" is limited to popular press and policy oriented media. According to him, "the last time water has played the main role in instigating a war was 4500 years ago" between Lagash and Umma over rights to use Tigris River in modern day Iraq (Dinar, 2007:22). Military clashes between countries purely over water have rarely ever occurred and are unlikely to occur in the future (Mauelshagen, 2009). Universally water-related conflicts tend to be internal and take place between local groups and not between states (Gamaliel \& Mwagiru, 2017:62).

Historical records confirm over 3500 water agreements compared to the small number of military confrontations over freshwater, of which the earliest dates back to some 
1200 years ago (Dinar, 2007:29). Priscoli argues that water agreements have actually prevented major conflicts such as on the subcontinent between Pakistan and India. Also Allan tries to disprove the popular intuition that scarcity of water will necessarily lead to water wars by giving an example about the Middle East where no signs of a water war has been observed since some minor military events in the northern Jordan Valley in the early 1960s. "On the contrary, there is much evidence of cooperation over scarce water resources in the region, especially in the Jordan River Basin, where freshwater is scarcest" (Allan, 2002: 256). According to United Nations Environment Programme, even the world's most vociferous enemies have negotiated water agreements or are in the process of doing so, and the institutions they have created often prove to be resilient, even when their relations are strained (Wolf, 2005:10). Wolf believes that despite the potential for dispute in international basins, the record of acute conflict over water resources is historically overwhelmed by the record of cooperation (Wolf, 2007:20).

Nevertheless some other scholars come up with opposite facts proving that water has always played a pivotal role in many historical wars. For example, Gleick believes that history of water conflicts dates back to 5000 years ago (Gleick, 1993:80) and "water and water supply systems have been the causes and instruments of war" (Ibid: 83). His search in historical records yields different results as he says that in $700 \mathrm{BC}$, Ashurbanipal of Assyria seized control of water wells to deprive rival Arabia of their water supply, and war over water in the Middle East continued into 20th century when the 1967 War broke out between Israel and its neighboring Arab states in the wake of the attempt of Arab League to divert Jordan River away from Israel, at least as one of the war reasons (Ibid: 85). Also some scholars highlight 38 acute disputes between 1948 and 2008, of those, 31 were between Israel and one or more of its neighbors. Yet most of the cases are believed to be either political tensions or instability rather than true acts of war, or involved using water as a tool, target, or victim of armed conflict (Petersen-Perlman, Veilleux, \& Wolf, 2017:107). Though there is evidence that tends to support the view that control over the sources of the Jordan River had some influence in the 1967 war between Israel and Syria, Egypt and Jordan (Zeitoun, 2011:3).

This controversy may have something to do with different types of shared water resources. The water resources that tie everyone's benefits up with each another seem less likely to foment conflicts. Such water resources are contingent on interaction and cooperation from all par- ties in order to keep running. Different components of such water resources (such as water catchment, water source, hydraulic structures, management system, and so on) are located and relatively scattered on both sides of the border, while benefiting the both sides. Therefore the both sides have to contribute to the water supply system whose operation hinges on their mutual collaboration.

This study also considers the difference between natural and artificial water resources. Wolf differentiates between two types of water resources which give rise to two different approaches toward them. According to him, spirituality underlies such a water dualism. For example he says: "different Islamic legal tenets apply to different water sources, basically divided by whether the water is 'provided by God' (i.e. from a natural surface or groundwater source which is available year-round) or whether it is 'provided by man' (i.e. the human labor which creates a cistern or the attendant canal system). 'God-given' waters may not be bought or sold, and their use is available to all equally. To many, the idea of buying and selling water is both repugnant (Wolf, 2012:82). We may say that the difference between two types of water resources or streams has been reflected in our spiritual beliefs.

Natural water streams are more of a bonanza whose operation and maintenance do not require much human skill and cooperation between communities. Therefore their utilization brings about competition rather than cooperation. In this study some examples of this situation have been given. On the contrary, the man-made canals and conduits tend to foster cooperation and mutual interaction between the beneficiaries and this situation can be the result of or caused by "territorial uncertainty" at the same time. Danube River along with its man-made canals is a well-known international example, which has been used for navigation and transportation since long time ago, connecting many regions in Europe.

The main Danube and its 60 tributaries are all shippable, some of which like Tisa-Danube Canal, DanubeBlack Sea Canal (with the length of $64 \mathrm{~km}$ ) and RhineMain-Danube Canal (with the length of $171 \mathrm{~km}$ ) have been built by human for the purpose of navigation. Transportation of considerable amount of commodities through these shippable canals could have entwined the economic destinies of many European countries, the way qanat system does on a smaller scale. In 1948, seven European countries proceeded to establish Danube Commission which was in charge of reinforcing cooperation between the member states in order to ensure free shipping in Danube, albeit the initial idea of this commission 
dates back to 1856 . Later some other countries joined the commission and now it includes Austria, Bulgaria, Croatia, Germany, Moldova, Hungary, Slovakia, Romania, Russia, Ukraine and Serbia (The European Federation of Inland Ports, 2014).

Inevitable cooperation in Danube region helped lessen territorial identity and moderate territorial identity accordingly paved the way for closer cooperation. As a result, in December 2013, Danube Transnational Cooperation Programme was signed between 14 European countries out of which 9 countries are among the European Union members. Danube Transnational Cooperation Programme has been envisaged for the years 2014 to 2020 and it has expanded cooperation beyond the issue of shipping in Danube into social, political and environmental realms (European Union, 2013). Danube Commission probably paved the way for European Union to come into existence. This example shows how artificial water canals can lead to the genesis of a "cooperationterritorial, uncertainty-cooperation" cycle.

If this hypothesis proves true that waning territorial identity leads to closer cooperation and interaction between two or more territories, the other elements should still be factored in. Another factor that contributes to the territorial uncertainty is the dispersal of vital resources over the central plateau of Iran. In other words, such vital resources as fresh water, arable soil, favorable climate, and so on are scattered over a wide geographical area and cannot be placed within a specified territory. For example, fertile soil suitable for cultivation is found somewhere far away from fresh water resources and water may be found in the area where arable soil is not available.

In fact, the close and self-sufficient territories are very rare in this region. Therefore, the third hypothesis of this study can be set out as follows: spatial dispersal of vital resources like fresh water and arable soil over the central plateau of Iran reduces the possibility of determining certain territories which are expected to contain all essential resources needed for the survival of the territory holders. This situation can in turn lead to a feeble territorial identity and then stronger sense of cooperation across the borders.

\section{Entrepreneurship}

Social and economic capacities of qanat territorial cooperation are appropriate prerequisite for efficient entrepreneurship which is regarded as one of the important strategies in rural development (Buzarjmehri, Roomiani, \& Esmaeili, 2015:453). Feeble territorial identity caused by qanat mechanism can facilitate cooperative connections in order to jointly utilize different vital resources scattered on both sides of a territorial border. In fact, qanat territorial cooperation helps raise social capital which is a crucial prerequisite for entrepreneurship. One of the significant factors in rural development is entrepreneurship which plays an important role in improving economic condition of villagers by opening up new opportunities for employment.

That is why the decision making bodies place a high value on the assessment of rural entrepreneurship and its impact on the process of rural development. Therefore development of rural entrepreneurship serves as a potential for diversification of economic sectors in order to reduce the risk of rural livelihood and enhance sustainable food security in the rural regions. Rural entrepreneurship can provide the local communities with a variety of agricultural and non-agricultural activities. In the new theories of development, rural entrepreneurship is discussed as a way leading to sustainable development by empowering rural communities and bridging the gap between city and village (Molla Shahi, Tabrizi Dokhtfard, 2014:30). In rural regions entrepreneurs give momentum to the economic development which eventually leads to higher welfare and better life condition of low income social classes, and then the result steps up the national development.

Rural development is a pivotal element of sustainable development, and nowadays entrepreneurship stands out as an important factor in sustainable development through mitigating unemployment and consequent social problems, improving life quality, distributing wealth, and utilizing local potentials. Therefore entrepreneurship has always existed as a key component of rural development and prosperity (Buzarjmehri et al, 2015:462). Rural entrepreneurship has been defined as establishing a new mechanism which introduces new services or products or creates new markets or uses new technologies in rural areas. It is necessary to determine all the factors that can impact the success of entrepreneurship, and examine its potentials to empower rural communities and promote their economic situation (Najafi Kani, Hesam, \& Ashor, 2015:40).

Entrepreneurship can establish a new order for work in rural areas, which enjoys three characteristics: 1- it is rational, because people have more control over their work in rural environment and seize more opportunities to gain from the profit of their work to satisfy such needs as social and cultural development, 2 - it is more humane, because people are not exploited for the jobs which are fully out of their social, environmental and psychologi- 
cal contexts, and 3- it is more compatible with environment, because the work comes out of the existing ecological cycles and is in perfect harmony with nature (Najafi Kani et al., 2015:41).

The book "Rural Development with an Emphasis on Entrepreneurship" has provided comprehensive definitions of rural entrepreneurship in Iran, which all stress its role in rural development as a process. The authors contend that the today rural communities in Iran are challenged with a variety of problems from geographical isolation, elderly population, migration, feminization of rural population, inefficient cropping pattern, water scarcity, lack of economic diversity to suspension of social potentials, and entrepreneurship can be regarded as one of the possible solutions (Eftekhari \& Sojasi Qeidari, 2010).

\section{Acknowledgments}

Special thanks go to the Faculty of Geography, University of Tehran which paved the way for this study by providing us with required information and documents. This paper is a part of Majid Labbaf Khaneiki's PhD dissertation conducted under Mohammad Reza Rezvani's supervision.

\section{Conflict of Interest}

The authors declared no conflict of interests.

\section{References}

Aghpour, E., Mazaheri, B., Avazeh, A., \& Vahedi, S. (2012) [Evaluating the relationship between Quran commands and marital satisfaction in family (Case study: Families living in Marand city) (Persian)]. Journal of Quran and Medicine, 1(3), 61-5.

Allan, J. A. (2002). Hydro-peace in the Middle East: Why no water wars?: A case study of the Jordan river basin. SAIS Review, 22(2), 255-72. doi: 10.1353/sais.2002.0027

Ambrosio-Albalá, M., \& Bastiaensen, J. (2010). The new territorial paradigm of rural development: Theoretical foundations from systems and institutional theories. Antwerp: University of Antwerp.

Ansari, M., Jamshidi, S., \& Almasifar, N. (2010). [To investigate feeling of territory and in territory traveling in urban parks, case study: Saee park (Persian)]. Armanshahr Architecture $\mathcal{E}$ Urban Development, 3(4), 33-48.

Antoci, A., Sacco P. L., \& Vanin P. (2010). On the possible conflict between Economic growth and social development. In G. Benedetto, \& R. Sugden (Eds.), Economics and Social Interaction: Accounting for Interpersonal Relations (pp. 150-73). Cambridge: Cambridge University Press.
Beard, V. A. (2005). Individual determinants of participation in community development in Indonesia. Environment and Planning C: Government and Policy, 23(1), 21-39. doi: 10.1068/c36m

Bebbington, A., Bebbington, D. H., \& Bury, J. (2011). Federating and defending: Water, territory and extraction in the Andes. In R. Boelens, D. Getches, \& A. Guevara-Gil (Eds.), Out of the Mainstream: The Politics of Water Rights and Identity in the Andes (pp. 307-327). Abingdon: Routledge.

Behnia, A. (1988). [Building of maintaining Qanat (Persian)]. Tehran: Markaz-e Nashr-e Daneshgahi.

Bonine, M. E. (2004). From Qanat to Kort: Traditional irrigation terminology and practices in Central Iran [M. Labaf Khaniki Persian Trans]. Rasaanaab Journal, 1(21, 22, 23, 24), 3-10.

Buzarjmehri, K., Roomiani, A., \& Esmaeili, A. (2015). [Investigating the factors affecting the growth of entrepreneurship in promoting rural communities for sustainable development (Persian)] Paper presented at The National Conference on Sustainable Rural Development in the Sixth Development Plan of the Country, Tehran, Iran, 4 February 2015.

Ogilvie, S. C. (2008). Protoindustrialization. In S. N. Durlauf, L. E. Blume (Eds.), The New Palgrave Dictionary of Economics, Second Edition. Cambridge: University of Cambridge.

Coleman, J. S. (1988). Social capital in the creation of human Capital. American Journal of Sociology, 94, S95-S120. doi: $10.1086 / 228943$

Creswell, J. W. (2012). Scholarly Articles for Research Design: (Quantitative, Qualitative and Mixed Method Approaches) [H. Danaee Fard, \& A. Salehi Persian Trans.]. Tehran: Ketab- e Mehraban.

Dinar, SH. (2007). Water wars? Conflict, cooperation, and negotiation over transboundary water. In V. I. Grover (Ed.), Water: A Source of Conflict or Cooperation? Boca Raton, Florida: CRC Press.

Eftekhari R., \& Sojasi Qeidari, H. (2010). [Rural Development with Emphasis on Entrepreneurship (Persian)]. Tehran: Samt.

European Union. (2013). Danube Transnational Cooperation Programme: A Stream of Cooperation. Brussels: European Union.

Fadavi, J. (2012). Field research method in human studies. In R. Salehi Amir, S. Fathi (Eds.), Qualitative Research Methods in Social Research (pp. 211-216). Tehran: Center for Strategic Research.

Flick, U. (2012). An Introduction to Qualitative [H. Jalili Persian Trans]. Tehran: Nasr-e Ney.

Gamaliel, A., \& Mwagiru, M. (2017). Constraints in implementing international water treaties: A case study of Nile basin treaty of 1929. Strategic Journal of Business and Change Management, 4(3), 60-100.

Ghayour, H. A. (1991). [Qanat: A reconsideration of the Iranian irrigation system (Persian)]. Geographical Research, 23, 676-91.

Gleick, P. H. (1993). Water and conflict: Fresh water resources and international security. International Security, 18(1), 79-112. doi: $10.2307 / 2539033$

Goblot, H. (1992). Qanats: A Technique to Acquire Water [A. Sarvqad Moghadam, \& M. H. Papoli Yazdi Persian Trans]. Mashhad: Papoli. 
Hayami, Y. (2008). Social capital, human capital and the community mechanism: Toward a conceptual framework for economists. The Journal of Development Studies, 45(1), 96-123. doi: $10.1080 / 00220380802468595$

Howell, D. L. (1992). Proto-industrial origins of Japanese capitalism. The Journal of Asian Studies, 51(2), 269-86. doi: $10.2307 / 2058029$

Hsu, C. C., \& Sandford, B. A. (2007). The Delphi technique: Making sense of consensus. Practical Assessment, Research and Evaluation Journal, 12(10), 1-8.

Khalili, M. (2011). [The concept of territory in the constitution of the Islamic republic of Iran: Geographical frontiers and doctrinal borderlessness (Persian)]. Rahbord Journal, 20(58), 7-46.

Khodaverdi, H. (2008). Qualitative research methodology. Rahavard-e Siasi, 21, 42-62.

Khanifar, H., \& Zarvandi, N. (2010). Qualitative research: A new approach in management studies. Rahbord Journal, 19(54), 24356.

Kriedte, P., Medick, H., \& Schlumbohm, J. (1981). Industrialization Before Industrialization. New York: Cambridge University Press.

Labbaf Khaneiki, M., \& Semsar Yazdi, A. A. (2015). [Qanat Tourism (Persian), Yazd: International Center on Qanats and Historic Hydraulic Structures (ICQHS), Iran Water Resources Management Company.

Labbaf Khaneiki, M. (2006). [Water Distribution Systems in Iran (Persian)]. Tehran: Ganjine-ye Meli Ab.

Levine, D. Z. (1977). Family Formation in an Age of Nascent Capitalism. Cambridge. Massachusetts: Academic Press.

Mahdavi, S. M. S., \& Hashemi, K. (2010). [Sociological study of the impact of education on human relationships in the family (Persian)]. Pajooheshhay-e Jam'ee Shenakhti, 4(4), 55-82.

The European Federation of Inland Ports. (2014). Towards an Optimal Integration of Inland Waterways in the Transport Chain. Brussels: The European Federation of Inland Ports.

Marshall, C., \& Rossman, G. B. (2002). Designing Qualitative Research [A. Parsaeian, \& M. Arabi Persian Trans]. Tehran Daftar-e Pajooheshhaye Farhangi.

Mauelshagen, F. (2009). Water politics: Conflict about limited resources. Paper presented at The Annual Meeting of the Catholic Academic Exchange Program, Bonn, Germany, 24 April, 2009.

McLachlan, A., McLachlan, K. S., Bonine, M. E., \& Beaumont P. (1989). Qanat, kariz, and khattara: Traditional water systems in the Middle East and North Africa. London: Middle East Centre.

Mendels, F. F. (1972). Proto-industrialization: The first phase of the industrialization process. The Journal of Economic History, 32(1), 241-261. doi: 10.1017/s0022050700075495

Mohammadpour, A. (2010). [Research plans with combined techniques: Paradigm principles and techniques (Persian)] Journal of Iranian Social Studies, 4(2), 106-41.

Mohammadpour, A. (2013). [Anti-method qualitative research (Persian)]. Tehran: Jame'e Shenasan.
Molla Shahi, G., \& Tabrizi Dokhtfard, E. (2014). [The importance of entrepreneurship and its role in the development of village communities (Persian)]. Nezam-e Mohandesi-ye Keshavarzi va Manabe'e Tabiee, 11(44), 28-32.

Najafi Kani, A. A., Hesam, M., \& Ashor, H. (2015). [The assessment of Entrepreneurship status in rural areas - Case: Southern Astarabad in Goragan (Persian)]. Journal Space Economy E Rural Development, 4(11), 37-56.

Papoli Yazdi, M. H., \& Labbaf Khaneiki, M. (2000a). [Combination of herds in the traditional livestock of Iran (Persian)]. Geographical Research, 15(1-2), 209-34.

Papoli Yazdi, M. H., \& Labbaf Khaneiki, M. (2000b). [Pasture: Operation systems (Persian)]. Geographical Research, 15(1-2),740.

Papoli Yazdi, M. H., Labbaf Khaneiki, R. A., Labbaf Khaneiki, M., Jalali, A., \& Vosooghi, F. (2000). [Qanats of Qasbeh, Gonabad: A Myth (Persian)]. Mashhad: Papoli

Papoli Yazdi, M. H., Labbaf Khaneiki, M. (2004). [The Qanats of Taft (Persian)]. Mashhad: Papoli

Papoli Yazdi, M. H., Labbaf Khaneiki, M. (2000). [Hermeneutics and interpretive Reflective research (Persian)]. Geographical Research,16(2), 6-20.

Petersen-Perlman, J. D., Veilleux, J. C., \& Wolf, A. T. (2017) International water conflict and cooperation: Challenges and opportunities. Water International, 42(2), 105-120. doi: $10.1080 / 02508060.2017 .1276041$

Priscoli, J. (2000). Water and civilization: Using history to reframe water policy debates and to build a new ecological realism. Water Policy, 1(6), 623-636. doi: 10.1016/s13667017(99)00019-7

Putnam, R. D. (2001). Bowling Alone: The Collapse and Revival of American Community. New York: Simon and Schuster.

Raven, P. H., Johnson G. B. (2001). Biology. Sixth Edition. New York : McGraw-Hill.

Reis, J. (2012). An epistemology of territory: a perspective on contexts for social relations. In P. Almeida Ashley, D. Crowther (Eds.), Territories of Social Responsibility: Opening the Research and Policy Agenda (pp. 93-106). Routledge: Abingdon.

Safinejad, J. (1989). [Traditional irrigation systems in Iran (Persian)]. Mashhad: Astan-e Ghods-e Razavi.

Safinejad, J. (1996). [Qanat of Ebrahim Abad the Most Ancient Qanat in Iran (Persian)]. Cultural and Artistic Researches Journal of Markazi Province, 3(4), 20-27.

Schick, T., \& Vaughn, L. (2010). How to Think About Weird Things: Critical Thinking for a New Age. New York: McGraw-Hill.

Semsar Yazdi, A. A., Labbaf Khaneiki, M., \& Dehghan Manshadi B. (2005). [A Survey on the Qanats of Bam from Technical and Engineering Point of View (Persian)], Tehran: UNESCO Tehran Cluster Office, ICQHS.

Semsar Yazdi, A. A., \& Labbaf Khaneiki, M. (2016). Qanat Knowledge: Construction and Maintenance. Berlin: Springer.

Silverman, D. (1985). Qualitative Methodology and Sociology: Describing the Social World. Lonon: Gower Pub Co. 
Smith, L. M., Bertozzi, A. L., Brantingham, P. J., Tita, G. E., \& Valasik, M. (2012). Adaptation of an ecological territorial model to street gang spatial patterns in Los Angeles. Discrete and Continuous Dynamical Systems, 32(9), 3223-44. doi: $10.3934 /$ dcds.2012.32.3223

Suarez-Villa, L. (1985). Industrialization in the development world: process cycles and the new global division of labour. The Canadian Journal of Regional Science. 8(3), 307-31.

Tadie, D., \& Fischer, A. (2013). Hunting, social structure and human-nature relationships in lower omo, Ethiopia: People and wildlife at a crossroads. Human Ecology, 41(3), 447-457. doi: $10.1007 /$ s10745-012-9561-9

Wolf Aaron, T. (2005). Hydropolitical Vulnerability and Resilience in International River Basins. Project of United Nations Environment Programme. Nairobi: United Nations Environment Programme.

Wolf, A. T. (2007). Shared waters: Conflict and cooperation. Annual Review of Environment and Resources, 32(1), 241-69. doi: 10.1146/annurev.energy.32.041006.101434

Wolf, A. T. (2012). Spiritual understandings of conflict and transformation and their contribution to water dialogue. Water Policy, 14(S1), 73-88. doi: 10.2166/wp.2012.010

Zeitoun, M. (2011). Power and Water in the Middle East: The Hidden Politics of the Palestinian-Israeli Water Conflict. New York: I.B.Tauris 
